\title{
Letter to the editor on respiratory mask using a combination of spunbond, meltblown, and activated carbon materials for reducing exposure to $\mathrm{CO}$ : an in vivo study
}

\author{
Muhammad Ifham Hanif ${ }^{1}$ (D) \\ Received: 29 July 2020 / Accepted: 19 November 2020 / Published online: 26 November 2020 \\ (C) Springer-Verlag GmbH Germany, part of Springer Nature 2020
}

The Environmental Science and Pollution Research 2020 released an article entitled Respiratory mask using a combination of spunbonds, meltblown, and activated carbon materials for reducing exposure to $\mathrm{CO}$ : an in vivo study. This article has broad implications for readers with their discoveries. Researchers tested the addition of respiratory mask media using activated carbon.

The addition of media to the breathing mask in principle increases the ability of the mask as an air filter in the form of particles, bacteria, and gas (Akduman and Akçakoca Kumbasar 2018; Wen et al. 2013; Lai et al. 2012; Wang et al. 2016). There is an addition of activated carbon in the granular form with a size of 325-350 mesh and dust content of less than $10 \%$, by the Indonesian National Standard. The test method uses a Wistar rat experiment placed on the box. The box is filled with a breathing mask material to be tested (Khayan et al. 2019, 2020).

In the method carried out by researchers, the concept of installing activated carbon is not explained in the spunbond and meltblown layers. The nature of activated carbon has the ability as adsorption on $\mathrm{CO}$ gas. The method used needs to explain the concept of gluing or combining activated carbon with spunbond and meltblown without eliminating the function of activated carbon.

The discovery of the media in improving the function of respiratory masks as personal protective equipment needs to be done in length so that the expected function can be optimal. Carbon monoxide (CO) is a poisonous gas. For this reason, further study is needed in the form of an ergonomic mask design that takes into account the level of gas leakage from the gaps of the mask, the concept of gluing the activated carbon media without eliminating function.

\section{References}

Akduman, C, and E P Akçakoca Kumbasar. 2018. "Nanofibers in face masks and respirators to provide better protection." In IOP Conference Series: Materials Science and Engineering, 460: 12013. IOP Publishing

Khayan K, Anwar T, Wardoyo S, Puspita WL (2019) Active carbon respiratory masks as the adsorbent of toxic gases in ambient air. $\mathrm{J}$ Toxicol 2019:1-7

Khayan K, Anwar T, Wardoyo S, Puspita WL (2020) Respiratory mask using a combination of spunbond, meltblown, and activated carbon materials for reducing exposure to CO: an in vivo study. Environ Sci Pollut Res. https://doi.org/10.1007/s11356-020-09476-8

Lai ACK, Poon CKM, Cheung ACT (2012) Effectiveness of facemasks to reduce exposure hazards for airborne infections among general populations. J R Soc Interface 9(70):938-948

Wang Q, Golshahi L, Chen DR (2016) Advanced testing method to evaluate the performance of respirator filter media. J Occup Environ Hyg 13(10):750-758. https://doi.org/10.1080/15459624. 2016.1177647

Wen ZB, Yu L, Yang WH, Hu LF, Li N, Wang J, Li JS, Lu JC, Dong XK, Yin Z (2013) Assessment the protection performance of different level personal respiratory protection masks against viral aerosol. Aerobiologia 29(3):365-372

Publisher's note Springer Nature remains neutral with regard to jurisdictional claims in published maps and institutional affiliations.

Responsible editor: Philippe Garrigues

Muhammad Ifham Hanif

muhammadifhamhanif@gmail.com

1 Medical Undergraduate Program, Faculty of Medicine, Universitas Padjadjaran, Bandung, Indonesia 